\title{
LEARNING STYLE AND LANGUAGE LEARNING STRATEGIES OF STUDENTS FROM VARIOUS ETHNICS IN INDONESIA
}

\author{
B. Widharyanto ${ }^{1 *}$, Heribertus Binawan ${ }^{2}$ \\ ${ }^{1}$ Universitas Sanata Dharma Yogyakarta, Indonesia \\ ${ }^{2}$ Universitas Mercu Buana Yogyakarta, Indonesia \\ *e-mail: bwidharyanto@usd.ac.id
}

\begin{abstract}
Learning styles, language learning strategies, and ethnicity are three important factors in language learning. The information about these three things is very useful for language teachers to prepare and implement effective language learning. This study was conducted to describe the students ' learning style and language learning strategy and to know the similarities/differences from the two elements of Java, Papua, Flores, Dayak, and Batak ethnics. A number of 175 participants were involved in the study. Research data were obtained through the Fleming's learning VARK questionnaire and a language learning strategy questionnaire from Oxford. The results of the two questionnaires were analyzed to determine the type of learning style and language learning strategy. The first finding suggests that the main learning styles of students from the five ethnics are variants [aural] and [kinesthetic] including variations in bimodal, and trimodal. The second finding shows that the major language learning strategy is metacognitive and affective. The third finding reveals some similarities and unique differences in their learning style and learning strategy.
\end{abstract}

Keywords: learning styles, language learning strategies, ethnics

\section{GAYA BELAJAR DAN STRATEGI BELAJAR BAHASA MAHASISWA DARI BERBAGAI ETNIS DI INDONESIA}

\begin{abstract}
Abstrak: Gaya belajar, strategi belajar bahasa, dan etnis adalah tiga faktor penting dalam pembelajaran bahasa. Informasi tentang tiga hal ini berguna bagi para guru bahasa dalam mengefektifkan penyusunan rencana pembelajaran bahasa dan pelaksanaan pembelajaran bahasa. Penelitian ini dilakukan dengan tujuan mendeskripsikan: gaya belajar, strategi belajar bahasa, serta persamaan dan perbedaan kedua hal tersebut pada mahasiswa etnik Jawa, Papua, Flores, Dayak, dan Batak. Sebanyak 175 partisipan dilibatkan dalam penelitian ini. Data penelitian diperoleh melalui Kuesioner Gaya Belajar VARK dari Fleming dan Kuesioner Strategi Belajar Bahasa dari Oxford. Hasil isian dua kuesioner tersebut dianalisis untuk mengetahui tipe gaya belajar dan tipe strategi belajar bahasa mereka. Temuan pertama menunjukkan bahwa gaya belajar yang dominan dari mahasiswa lima etnik adalah gaya belajar unimodal [Aural] dan [Kinestetik], beserta varian-variannya dalam wujud bimodal, dan trimodal. Temuan kedua menunjukkan bahwa strategi belajar bahasa yang dominan adalah strategi metakognitif dan strategi afektif. Temuan ketiga mengungkap bahwa ada persamaan dan perbedaan gaya belajar dan strategi belajar yang khas di antara mahasiswa kelima etnik.
\end{abstract}

Kata Kunci: gaya belajar, strategi belajar bahasa, etnis

\section{INTRODUCTION}

Neil D. Fleming has developed a model of students' learning style preference of visual, aural, read/write, and kinesthetic (VARK) since 1987. This model is a new development that refers to the existing learning style preference model of VAK (Visual, Aural, Kinesthetic). Fleming distinguishes the preferences of [Visual] modality with [Read/Write] modality because those two models seem to have different tendencies (Fleming, 2014). Referring to what Fleming has read and observed, it seems clear that some students obviously have their preference for written words while others prefer symbolic information or pictures such as maps, diagrams, and graphics. Both preferences are not always found in the same person. Since then, the learning style of the Fleming model 
has four modalities of preference namely Visual, Aural, Read / Write, and Kinesthetic which are formerly abbreviated as VARK (Fleming \& Bonwell, 2019).

Besides the general learning styles as stated by Fleming, language learning strategies are also widely applied in language learning. One of the prevalent language learning strategies is Oxford's model. Oxford (1990) formulated six main categories of language learning strategies; they are memory strategy, cognitive strategy, compensation strategy, metacognitive strategy, affective strategy, and social strategy. The six language learning strategies are then generally grouped into direct and indirect strategies. The direct strategy consists of memory strategy, cognitive strategy, and compensation strategy. Those three strategies under the direct strategy, they have similarities in the direct use of target language. The indirect strategy involves metacognitive strategy, affective strategy, and social strategy. This strategy is said to be indirect because its application is not directly related to the use of the target language.

Learning styles and language learning strategies are the two main factors that help to determine how and how well students master their second or foreign language (Oxford, 2003). O'Malley \& Chamot (1990) emphasized that learning strategies which consist of some aspects such as focusing on particular aspects of new information, analyzing and monitoring information, and organizing on new information during the learning process will be completed or assuring oneself. This learning process is successful as a way to allay anxiety that leads to students' learning achievement (Hardan, 2013). Related to the learning styles, Oxford states that when students are left independently and not encouraged by teachers or enforced by lessons to use a specific set of strategies, they naturally will use learning strategies that reflect their basic learning styles (Oxford, 2003). Oxford also said that teachers can actively help students "develop" their learning styles by applying strategies that are beyond their primary style or preferences.

However, in the latest research, there are other factors that can influence the success of language learning. One of them is ethnic identity. Trofimovich \&Turuševa (2015) say that ethnic identity refers to subjective experiences that will include feelings, experiences, and behaviors through which people take their position or membership in one or several ethnic groups. Subjective experience in ethnic identity will be obviously seen in their internal and external aspects as it is mentioned by Isajiw (Ali, Indrawati, \& Masykur, 2010). Internal aspects refer to images, ideas, attitudes, and feelings, which generally can be grouped into four dimensions: affective, trustworthy, cognitive, and moral. The external aspect is revealed through some observable behaviors including language dialect, practice of ethnic traditions, participation in ethnic networks such as family and friendship, and participation in organizations or institutions. Ethnic identity, especially in the case of English language learners in Iran, it significantly has a positive correlation with learners' language skills (Saadat \& Hosseini, 2015).

Information about the Fleming model of learning style and the Oxford model of language learning strategy as well as their connection to students' ethnic identities, will contribute some benefits to teachers in developing their language learning design. Teachers will be assisted in selecting and developing material of language course that is appropriate with the major styles and characteristics of the class, developing varieties and not-single learning methods, selecting activities that are suitable for students learning styles $(\mathrm{Xu}, 2011)$. This variation in students' ethnicities, in this case, is the tribes, according to Saddhono is actually the basis of multicultural class management method in learning (Gusnawati \& Nurwati, 2018). Politzer \& McGroarty of their study on investigating Asian and Hispanic students then theorize that ethnicity might have a strong influence on some effective strategies employed by students (Ghani, Khairisman, \& Samad, 2016).

Inspired by Oxford's view of the relationship between learning styles and language learning strategies (Oxford, 2003) and $\mathrm{Xu}$ 's findings about the implications of activities that are in line with learning styles in language learning (Xu, 2011), and Saddhono's view that students' ethnic variations are the basis of classroom management (Gusnawati \& Nurwati, 2018), this study describes the pattern of learning styles and language learning strategies from students with various ethnic backgrounds, who take Indonesian language course at a private university in Yogyakarta. 
The objectives of this study can be described as follows. First, to describe the types of students learning styles from ethnics of Javanese, Papuan, Flores, Dayak, and Batak. Second, to describe the language learning strategies undertaken by students who come from ethnics of Javanese, Papuan, Flores, Dayak, and Batak by considering their various learning styles preference. Third, to describe the similarities and differences of learning styles and language learning strategies among the Javanese, Papuan, Flores, Dayak, and Batak ethnic students.

\section{METHODS}

This research used a qualitative approach to describe the types of learning styles and language learning strategies of students from five ethnic groups. This study also attempted to listed the similarities and differences in learning styles and language learning strategies of the students.

The participants of this study were 175 students of the Indonesian Language and LiteratureEducationStudyProgram, semesterone and three, in a private university in Yogyakarta. They come from five ethnics, namely Java, Papua, Flores, Dayak, and Batak. In this course they take a total of 158 credits with details of 96 credits for national curriculum, which prepares them to be Indonesian teachers, and 52 credits for local curriculum, which develops them in the field of journalism and Indonesian language learning for foreign speakers. The average age of participants was 19.6 years old. The average academic achievement index is 3.09.

Table 1 shows the number of students voluntary participated in this study and their age and GPA average at the time of the research.

The use of questionnaires to obtain both data refers to Bessai's opinion stating that research in this field is more dependent on student selfreports, which are made by one of them through questionnaires. Questionnaires are a way to gain insight into the unobservable mental learning strategies of learners by asking them to reveal and describe their thought processes (Bessai, 2018). In addition, respondents themselves are closer to questionable problems than others and the information they provide in self-report questionnaires tends to be accurate (Demetriou, Ozer, \& Essau, 2015).

The learning style questionnaire used in this study was the VARK Questionnaire version 8.01. This questionnaire contains 16 statements that contain daily events that will be carried out and equipped with 4 choices of actions to be taken that describe the Visual, Aural, Read/Write, or Kinesthetic learning styles. Referring to the previous research (Robertson, Smellie, Wilson, \& Cox, 2011), the VARK Questionnaire version 8.01 provides researchers with some advantages at least in two aspects i.e. the scores that can be calculated quickly and the help sheets to articulate students' learning styles. Moreover, FitkovNorris, \& Yeghiazarian (2015) have validated the VARK Questionnaire using Rasch analysis and the results show that this instrument has the potentials to predict students' learning orientation preferences.

The language learning strategy questionnaire used in this study was Oxford's Strategy Inventory of Language Learning version 7.0 with some adaptations to the Indonesian context. This questionnaire has 50 statements about 6 dimensions of language learning strategies with details: 9 statements of Memory Strategies, 14 statements of Cognitive Strategies, 6 statements of Compensation Strategies, 9 statements of Metacognitive Strategies, 6 statements of Affective Strategies, and 6 statements of Social Strategies. Each item consisted of five answer choices by weight rating of 1 (never do at all), 2 (only occasionally or very rarely do), 3 (sometimes do), 4 (pretty

Table 1. The Number of Participants, Age Average, and GPA's Average

\begin{tabular}{llccc}
\hline No. & Ethnic Background & $\begin{array}{c}\text { The Number of } \\
\text { Participants }\end{array}$ & Age Average & GPA's Average \\
\hline 1. & Javanese & 90 & 19.2 & 3.38 \\
2. & Papuan & 25 & 21.4 & 2.32 \\
3. & Flores & 31 & 19.2 & 3.37 \\
4. & Dayak & 16 & 19.2 & 3.20 \\
5. & Batak & 13 & 19.0 & 3.20 \\
\hline
\end{tabular}


often but not always do), and 5 (always do).

This study also followed the backtranslation method (Son, 2018). VARK Questionnaire version 8.01 and Oxford's Strategy Inventory of Language Learning version 7.0 as one of the documentation tools also use back-translation. The questionnaires were translated into Indonesian and then re-translated into English by English linguists to develop the best-matched meaning and pick up substances to be explored by the items on the scale. Both of these questionnaires were then validated by Indonesian language learning experts to reveal the students' preferences in learning styles and language learning strategies.

Learning style profile data were analyzed with the following steps: identify participant responses, classify into the types of learning styles, classify into strong and weak preference using the following Fleming's criteria (Fleming, 1995), there is a strong preference that would usually be identified by a score for that preferences that was four or five points ahead of any other. Fleming also explained that the difference of one or two points between those preferences is not enough. If there is an answer with a score of 0 or a score of 1 in a particular mode, it clearly indicates that the student or teacher can be regarded as weak in using the particular mode. The last stage in this research is grouping the major learning styles into five existing ethnic groups and interpreting the learning style profile by paying attention to the type of style, the major style, and its relation to ethnic identity.

Language learning strategy profile data were analyzed with the following steps: identify participant responses, classify on a scale of 1 for never do at all, 2 for only occasionally or very rarely do, 3 for sometimes do, 4 for quite often but not always do, and 5 for always do. The criteria used are mean 1-3 values used as indicators for strategies not used by participants and mean values 4-5 are used as indicators for the strategies used by participants. The calculation of the mean value uses rounding with the criteria $\leq .4$ rounded down to .0 and $\geq .5$ rounded up to 1 . Then, determine the language learning strategies used by participants from five ethnic groups.

\section{FINDINGS AND DISCUSSION Findings}

The following describes the findings about learning styles, language learning strategies, and their similarities and differences of students from five ethnic groups in Indonesia.

\section{Student Learning Styles from the Five Ethnics in Indonesia}

The modality preference profile of student learning styles from the five ethnics shows the following characteristics. A few of the participants have one modality or unimodal of learning style and some others have more than one modality of learning style or multimodal that could be either bimodal, or trimodal. Denoting Fleming's criteria (Fleming, 1995), there is a strong preference would usually be identified by a score for that preference that was four or five points ahead of any other. Further, he explained that the difference of one or two points between the preferences is not sufficient. If there is an answer with a score of 0 or a score of 1 in a particular mode, it indicates that the student or teacher can be regarded as weak in using the mode. Table 2 shows the results of the analysis of student learning styles from the five ethnic groups. In this table, a strong preference term in a specific type of mode is called a major or dominant learning style.

The Javanese ethnic student group, they have two major learning styles i.e. bimodal [Aural-Kinesthetic] and [Kinesthetic-Aural] whose numbers reach up to $57 \%$. In Fleming's criteria, these two types of learning styles are

Table 2. Types of Student Learning Styles from the Five Ethnics

\begin{tabular}{llcccc}
\hline \multirow{2}{*}{ Ethnic Background } & \multirow{2}{*}{ Major } & \multicolumn{4}{c}{ Type of Learning Style } \\
\cline { 3 - 6 } & Learning Style & Unimodal & Bimodal & Trimodal & Quadrimodal \\
\hline Javanese & {$[\mathrm{AK}],[\mathrm{KA}]$} & $11 \%$ & $57 \%$ & $28 \%$ & $4 \%$ \\
Papuan & {$[\mathrm{AK}],[\mathrm{RVA}]$} & $14 \%$ & $35 \%$ & $40 \%$ & $11 \%$ \\
Flores & {$[\mathrm{KA}]$} & $26 \%$ & $57 \%$ & $13 \%$ & $4 \%$ \\
Dayak & {$[\mathrm{A}],[\mathrm{K}]$} & $62 \%$ & $19 \%$ & $19 \%$ & $0 \%$ \\
Batak & {$[\mathrm{AK}],[\mathrm{KAR}]$} & $23 \%$ & $31 \%$ & $39 \%$ & $7 \%$ \\
\hline
\end{tabular}


categorized as strong preferences than the other eleven learning styles. This finding shows that students from Javanese ethnic groups tend to have bimodal [Aural-Kinesthetic] and [Kinesthetic-Aural] learning style preferences. In attending various courses in the Indonesian Language and Literature Study Program, Javanese ethnic groups are divided into two sub-groups. First, those who prefer to learn by listening and speaking continued by gaining practical experience through the practices of drama, simulation, speech, dialogue, or activities that utilize the four senses such as sight, touch, taste, smell, and hearing. Second, those who prefer learning by gaining practical experience by practicing language and making use of the four senses, and being proceeded by listening and speaking.

The Papuan ethnic student group reveals two major learning styles, namely bimodal [Aural-Kinesthetic], and trimodal [Read/Write-Visual-Aural], which reach up 35\% and $40 \%$. Based on Fleming's criteria, these two types of learning styles are categorized as strong preferences compared to the other eleven learning styles. This finding shows that students from Papuan ethnic group tend to have bimodal [Aural-Kinesthetic] and trimodal [Read/WriteVisual-Aural] learning style preference. In attending various courses in the Indonesian Language and Literature Study Program, ethnic Papuan groups are divided into two sub-groups. The first subgroup prefers to learn by gaining practical experience through various physical practices or activities that utilize the four senses such as sight, touch, taste, smell, and hearing. The second subgroup prefers to combine written information with pictures or tables and end with listening and speaking.

The Flores ethnic student group has one major learning style particularly [KinestheticAural] or bimodal, which aggregates to 57\%. Referring to Fleming's criteria, the type of bimodal learning style [Kinesthetic-Aural] is categorized as strong preferences than the other fourteen learning styles. These findings show that students from Flores ethnic group prefer to attend the Indonesian Language and Literature Education Study Program classes by gaining practical experience through a variety of physical activities and being proceeded by listening and speaking.
The Dayak ethnic student group has two major learning styles especially unimodal [Aural] and [Kinesthetic] which reach numbers of $62 \%$. Based on Fleming's criteria, these two types of learning styles are categorized as strong preferences compared to the other nine learning styles. This finding shows that students from Dayak ethnic group can be clustered into two sub-groups with some variations as follows. First, those who prefer to learn Indonesian by listening and speaking. Second, those who prefer to learn by gaining practical experience through physical practices or utilizing their four senses.

The Batak ethnic student group has two major learning styles, namely bimodal [AuralKinesthetic], trimodal [Kinesthetic-Aural-Read/ Write] which reaches a number of $31 \%$ for the bimodal and 39\% for the trimodal. Based on Fleming's criteria, these two types of learning styles are categorized as strong preferences than the other nine learning styles. This finding shows that students from Batak ethnic group can be grouped into two subgroups with the following variations. First, those who prefer to learn by combining listening and speaking by gaining practical experience through various physical practices or activities that utilize the four senses such as sight, touch, taste, smell, and hearing. Second, those who prefer to learn Indonesian through physical practice activities to gain practical experience, followed by speaking and listening, and ended with reading and writing activities.

\section{Language Learning Strategies of Students from Five Ethnics in Indonesia}

Each item in Oxford's Strategy Inventory of Language Learning version 7.0 consists of five answer choices by weight rating of 1 for never do at all, 2 for only occasionally or very rarely do, 3 for sometimes do, 4 for quite often but not always do, and 5 for always do. In this language learning strategy, a strategy is said to be used by certain ethnic groups when the average scale ranges between quite often and always or mean values of 4-5. Conversely, a strategy is not used by certain ethnic groups when the average scale ranges between 'never do at all' and 'sometimes do' with its mean values of 1 to 3 .

$$
\text { Based on those particular }
$$
criteria, the language learning strategy profile of students from the five ethnics in 
Indonesia shows the facts as shown in Table 3.

It is known that indirect strategies, such as metacognitive, affective, and social strategy, are more widely used by students from different ethnicities than direct strategies, namely memory, cognitive, and compensation strategies. The direct strategy involves the use of the target language or the language studied directly to facilitate the learning process and the indirect strategy is to provide indirect support in the language learning performed (Oxford, 1990). Javanese and Flores use three indirect strategies and use only one direct strategy. Batak uses two indirect strategies and one direct strategy. Papuans and Dayak use two indirect strategies and do not use direct strategies at all. The six language-learning strategies used by five ethnic group students are described below.

Memory strategy which relates to how students remember language is not used by all students from the five ethnic groups. In other words, none of these five ethnic students use a memory strategy to learn Bahasa Indonesia. Memory strategy emphasizes more on efforts to remember (save and recall) linguistic material. This strategy consists of four sub-strategies, namely creating mental relationships, using visual impressions and sounds, reviewing them well, and taking action. Memory, cognitive and compensation strategies are part of the direct strategies as depicted in the taxonomy of language learning strategies by Oxford.

Cognitive Strategy which relates to how students think about their learning is used by groups of Javanese, Flores and Batak ethnic students in learning Indonesian. Papuan and Dayak ethnic student groups do not use this strategy. Cognitive Strategies have four substrategies. Sub strategy using Indonesian is done in the form of practicing formally and naturally, repeating activities, and using standardized language formulas and patterns. Sub strategy of receiving and sending messages in Indonesian is implemented in the form of getting ideas quickly and using various sources. Sub strategy of analysing and reasoning is applied in the form of analysing expressions and transferring. Sub strategies create structures for input and output applied in the form of marking, taking notes, summarizing, structuring ideas, conceptualizing, and making charts.

Compensation Strategy which enables students to make up for limited knowledge is like memory strategy; it is not used by these five students' Ethnic groups of Javanese, Papuan, Flores, Dayak, and Batak. In other words, none of these five ethnic students use a compensation strategy to studyBahasa Indonesia. Compensation Strategy is a strategy intended to overcome deficiencies and disabilities in language. This strategy consists of two sub-strategies, namely guessing cleverly and overcoming limitations.

Metacognitive strategy which relates to how students manage their own learning) is used by the five ethnic groups in learning Indonesian. This strategy includes two substrategies. First, the sub-strategy organizes and plans to learn activities carried out in the form of finding and creating opportunities, organizing, identifying, determining goals or language assignments. Second, evaluating sub-strategies is implemented in the form of self-monitoring in learning Indonesian. Metacognitive, affective and social strategies are part of the indirect strategies as depicted in Oxford's taxonomy of language learning strategies.

Affective strategy which relates to students' feeling is used by the five ethnic groups in learning Indonesian. This strategy presents elements of leisure, pleasure, calmness, enthusiasm, and other emotional aspects. Affective strategies consist of three substrategies such as reducing anxiety, pushing oneself and taking emotional temperature. The first and second sub- strategies were used by all students from the five ethnics namely Javanese, Papuan, Flores, Dayak, and Batak. Sub strategy to reduce anxiety is done using music, relaxation, and deep breathing, and being indifferent, speaking aloud, and speaking in the mirror. Selfencouraging sub-strategy is applied in the form of making positive statements, appreciating self-success, and dare to take risks. The Social Strategy is used by Javanese and Flores ethnic groups. Three other ethnic groups do not use this social strategy.

Social strategy which involves learning by interaction with others is a learning strategy by involving other people. Social strategy includes three sub-strategies. First, the substrategy of asking the other party, it is used in the form of asking for clarification and asking for a correction. Second, the cooperation sub-strategy is implemented in the form of asking peers or 
asking more experts. Third, the sub-strategy of empathizing with others. The first and second strategy were used by students from ethnics of Javanese and Flores while the Papuan, Dayak and Batak, they did not use this social strategy.

\section{Similarities and Differences in Learning Styles and Language Learning Strategies of the Five Ethnic Groups}

Javanese, Papuan, Flores, Dayak, and Batak students' ethnic groups at a private university in Yogyakarta, show similarities and differences in the learning styles and the use of language learning strategies. These similarities and differences can be seen in Table 4 .

The following findings describe the similarities and differences in the learning styles of students from the five ethnic groups. The similarity in learning styles of the five ethnic groups is seen in the [Aural] and [Kinesthetic] elements that appear either as unimodal types or forming elements of the bimodal, and trimodal learning styles. Variations in the formation of bimodal learning styles in the five ethnic groups include [Aural-Kinesthetic], and [KinestheticAural]. Variations in the type of trimodal learning style with a combination of elements [Visual] and [Read/Write] include: [Read/Write-VisualAural], and [Kinesthetic-Aural-Read / Write].
Thus, the equation of learning styles of students from the five ethnic groups always contains the major elements [Aural] and [Kinesthetic]. The difference seen in the learning styles of students from the five ethnic groups is in the type of bimodal and trimodal learning styles. The [Visual] and [Read/Write] learning style elements only appear in groups of ethnic Papuan students. These two elements do not appear in the Javanese, Flores, Dayak, and Batak ethnic students' groups. Meanwhile, the [Read/Write] learning style element only appear in Papuan ethnic students.

The similarities and differences in language learning strategies can also be seen in Table 4. Javanese and Flores ethnic group students use the same four language learning strategies, namely Cognitive, Metacognitive, Affective, and Social strategies. Papuan and Dayak ethnic student groups use the same two language learning strategies, namely the Metacognitive and Affective strategies. The Batak ethnic group of students used three language learning strategies, namely Cognitive, Metacognitive, and Affective, which were the same as Javanese and Flores except for Social. The five ethnic group students were also the same in terms of using the Metacognitive and Affective strategies, and the same in terms of not

Table 3. Five Ethnic Student's Language Learning Strategies

\begin{tabular}{|c|c|c|c|c|c|c|}
\hline \multirow{2}{*}{$\begin{array}{l}\text { Ethnic } \\
\text { Background }\end{array}$} & \multicolumn{6}{|c|}{ Language Learning Strategies } \\
\hline & Memory & Cognitive & Compensation & Metacognitive & Affective & Social \\
\hline Javanese & - & $\mathrm{V}$ & - & $\mathrm{V}$ & $\mathrm{V}$ & $\mathrm{V}$ \\
\hline Papuan & - & - & - & $\mathrm{v}$ & $\mathrm{v}$ & - \\
\hline Flores & - & $\mathrm{v}$ & - & $\mathrm{v}$ & $\mathrm{v}$ & $\mathrm{v}$ \\
\hline Dayak & - & - & - & $\mathrm{v}$ & $\mathrm{v}$ & - \\
\hline Batak & - & $\mathrm{v}$ & - & $\mathrm{v}$ & $\mathrm{v}$ & - \\
\hline
\end{tabular}

Table 4. Five Ethnic Student's Major Learning Style and Language Learning Strategies

\begin{tabular}{|c|c|c|c|c|c|c|c|}
\hline \multirow{2}{*}{$\begin{array}{l}\text { Ethnic } \\
\text { Background }\end{array}$} & \multirow{2}{*}{$\begin{array}{l}\text { Major } \\
\text { Learning } \\
\text { Style }\end{array}$} & \multicolumn{6}{|c|}{ Language Learning Strategies } \\
\hline & & Memory & Cognitive & Compensation & Metacognitive & Affective & Social \\
\hline Javanese & {$[\mathrm{AK}],[\mathrm{KA}]$} & - & $\mathrm{v}$ & - & $\mathrm{v}$ & $\mathrm{V}$ & $\mathrm{v}$ \\
\hline Papuan & {$[\mathrm{AK}],[\mathrm{RVA}]$} & - & - & - & $\mathrm{v}$ & $\mathrm{v}$ & - \\
\hline Flores & {$[\mathrm{KA}]$} & - & $\mathrm{v}$ & - & $\mathrm{v}$ & $\mathrm{v}$ & $\mathrm{v}$ \\
\hline Dayak & {$[\mathrm{A}],[\mathrm{K}]$} & - & - & - & $\mathrm{v}$ & $\mathrm{v}$ & - \\
\hline Batak & {$[\mathrm{AK}],[\mathrm{KAR}]$} & - & $\mathrm{v}$ & - & $\mathrm{v}$ & $\mathrm{v}$ & - \\
\hline
\end{tabular}


using the Memory and Compensation strategy in learning Indonesian. The difference seen in the use of language learning strategies of the five ethnic students is in the Cognitive and Social strategies. Javanese, Flores and Batak ethnic groups use Cognitive strategies, while ethnic Papuan and Dayak student groups do not use them. Furthermore, the Social strategy is only used by ethnic Javanese and Flores, but they are not applied by ethnics of Papuans, Dayaks, and Batak.

\section{Discussion}

\section{Learning Style Profile}

The finding of the learning style of students from Javanese, Papuan, Flores, Dayak, and Batak ethnics attending Indonesian language courses clearly show that the learning styles of [Aural] and [Kinesthetic], either as a unimodal, bimodal or trimodal - forming elements, are considered as the most major learning style. The major learning style of five ethnic students at a private university in Yogyakarta tends to use the sense of hearing, experience, and practices. In Fleming's criteria, these are considered as the strong preferences.

The students with aural modality preference, they rely on the ears or hearing senses in capturing and understanding the information. This mode of perception depicts their preference for spoken or heard information. The student with this modality, they learn best through activities such as discussions, verbal feedback, asking questions, emailing, cellphone-chats, sending SMS (Short Message Service), board discussions, oral presentations, classes, tutorials, and talking with others. Success in capturing and understanding information is highly reliant on the formulating of particular information. If information is presented in the form of recordings, presentations, stories, or reading aloud, the learners with aural style preferences will be happier, more comfortable, and easier to capture the information.

The students with kinesthetic modality preferences, they prefer to obtain information through some practical activities that involve physical experience in learning in the classroom or outside the classroom. Experience is considered significant for kinesthetic learners. Activities such as experimenting, creating crafts, demonstrating movements, playing drama or role-playing, are activities that they are highly interested in.

These findings are classified as what is called the "general approach" in language learning (Oxford, 2001) that are applicable to the Indonesian language courses. The development of variations in the style of learning in particular [Aural] and [Kinesthetic] as elements of formation in bimodal, and trimodal as shown in Table 2, are also aligned with the following Fleming statement.

... it is not possible that populations with VARK data will point more than $40 \%$ have one preference. And, a single preference indicates the strength of one modality which is not indicative that the other three VARK modalities do not exist (Fleming, 2012: 1).

The variance of the [Aural] and [Kinesthetic] learning styles, as a bimodal and trimodal formation element, is shown in Table 2. These variations are seen in the types of bimodal [Aural-Kinesthetic], [Kinesthetic-Aural] and trimodal [Kinesthetic-Aural-Read/Write], [Read/Write-Visual-Aural]. The variance in the learning style of the five students' ethnic group show that [Aural] is very dominant because it is part of the forming learning style of the five students' ethnic groups. Compared to the previous research in Asia, as reported by Reid in Oxford (Oxford, 2003) it is stated that students from Asian cultures were often highly visual, for instance Koreans are most visual. Many of the Hispanic learners were frequently very auditory but Reid also discovered that Japanese were very non auditory. So in this case, these findings appear that the Indonesian students from the five different ethnics seem to be very auditory as it happened in the Hispanic learners.

This learning style profile findings from these five ethnic groups carry a clear pedagogical impact. Lecturers must prepare a teaching plan to accommodate a wide range of learning styles from the five ethnic groups, namely Java, Flores, Batak, Papua, and Dayak. This is in accordance with the most common hypothesis about the instructional relevance of learning style which is called as the meshing hypothesis, "that instruction should be provided in the mode that matches the learner's style." (Pashler, Mcdaniel, Rohrer, \& Bjork, 2009:10). Learning will not be effective, or at least less efficient, if learners receive 
clues that do not match their learning style, or conversely, that individualistic instruction based on student style can support students to achieve better learning outcomes.

\section{Language Learning Strategies Profile}

The findings of the language learning strategies of students from various ethnic groups in the Indonesian language class show that the metacognitive and affective strategies are the "general" language learning strategies. This means that students from five ethnic groups have the same characteristics especially in making arrangements for their own language learning process, and seeking comfort, calmness, enthusiasm, and other emotional aspects in learning Indonesian. Some other strategies, such as cognitive and social, are only used by a few ethnic groups. The Cognitive strategy is applied by Javanese, Flores and Batak ethnic groups while the Social strategy is applied by Javanese and Flores ethnic groups. On the other hand, the Memory and Compensation strategy are not used by all students from five ethnic groups.

Related to the findings of learning styles and language learning strategies in this study, it can be said that there is a relationship between learning styles [Aural] and [Kinesthetic] and their variants in bimodal and trimodal types with the selection and use of the Metacognitive Language Learning Strategies and Affective Language Learning Strategies. These findings correspond to the study results of Jie \& Qin stating that learning styles have a significant influence on learners' learning strategy choices (Jie \& Qin, 2006). Learning styles contributed to the tendency of individuals to choose certain learning strategies. The findings also support the results of the Oxford' Study:

that once learners are aware of their own learning styles, it enables them to adapt their learning strategies to suit different learning tasks in particular contexts. Learners can take advantage of their learning styles by matching learning strategies with their styles; similarly, learners can compensate for the disadvantages of their learning styles to balance their learning by adjusting learning strategies (Wong \& Nunan, 2011: 146).
The statements of Jie \& Qin (2006) and Oxford quoted by Wong \& Nuna (2011) are seen in the case of two ethnic groups i.e. Javanese and Flores students. Their major learning styles are [Aural-Kinesthetic] in a combination of a bimodal, and in language learning strategies, they use the same strategy, namely Cognitive, Metacognitive, Affective, and Social. Meanwhile, in the case of ethnic Papuan and Dayak student groups, those two ethnic groups do not have major learning style because they tend to have different learning styles. The Papuan and Dayak, they both use only two language learning strategies, namely Metacognitive and Affective. Furthermore, in the case of Batak student groups, which have major bimodal of [Aural - Kinesthetic] learning styles and trimodal of [Kinesthetic-Aural-Read/Write]. The Batak ethnics use three language learning strategies, namely Cognitive, Metacognitive, and Affective. The Batak ethnics appear to be the most unique in using combination of the three language learning strategies compared to the other four ethnics.

In relation to being a prediction of language skills, the findings presented in Table 4 show an interesting phenomenon and need to be followed up with quantitative research to see the relationship or influence of language learning strategy variables on Indonesian language learning achievement of students from various ethnic groups. The fact is that certain ethnic group students use language-learning strategies more than other ethnic groups. The ethnic of Javanese and Flores student groups use four learning strategies, the Batak ethnic student group uses three language learning strategies, and the ethnic Papuan and Dayak student groups only use two language learning strategies.

Further research is expected to prove a hypothesis about the relationship or influence between the six language learning strategies, especially the four learning strategies applied in this research and the language proficiency in Indonesia's context. This view was inspired by Rao's research on the relationship between the use of language learning strategies and English proficiency (Rao, 2016). Rao found that students' English proficiency significantly influenced the use of their learning strategy, with high-level students using more strategies and more often than low-level students. Further, Rao also reveals that there are several characteristics 
of the use of language learning strategies from each group of students.

\section{The Similarities and Differences in Learning Styles and Language Learning Strategies}

From the findings of the similarities and differences in learning styles and language learning strategies of students from various ethnicities, as described in Table 4, there are some interesting phenomena. The Javanese and Flores ethnic student groups have a learning style of bimodal [Kinesthetic - Aural] and language learning strategies that tend to be the same namely in Cognitive, Metacognitive, Affective and Social.

A phenomenon happened to Papuan and Dayak ethnic student groups. They have a different learning styles but on the contrary, they share the same language learning strategies, especially in using Metacognitive and Affective language learning strategies.

These findings show that there are similarities in learning styles and language learning strategies between several ethnic groups, but on the other hand, there are also different tendencies from other ethnic groups. These phenomena clarify what Brown has stated in (Jie \& Qin, 2006) that language learning strategies do not operate independently but they are influenced by learning styles. An illustration of these findings is described in Figure 1.
It can be found some similarities and differences as follows. Javanese and Flores ethnic student groups have learning styles and language learning strategies that tend to be similar. Meanwhile, Papuan and Dayak ethnic student groups, they do not share similarities in learning styles but they tend to apply similar language learning strategies such as Metacognitive and Affective language learning strategies. On the other hand, Cognitive and Social language learning strategies that are applied to Javanese, Flores, and Batak are not applied to Papuan and Dayak. The Social language learning strategy is applied by Javanese, Papuan, Flores and Dayak but it is not applied by Batak students.

These findings of the similarities and differences in language learning strategies of students from various ethnic groups are interesting especially that they are related to Saadat \& Hosseini's explanations about the role of ethnicity in the motivation to learn second languages (Saadat \& Hosseini, 2015). In addition, they stated that some studies show that students who feel less strongly associated with their ethnic identity tend to learn longer than their more assertive peers. They also affirm that although integrative and instrumental orientation plays a strong role in L2 motivation, the effect of ethnic identity is quite significant.

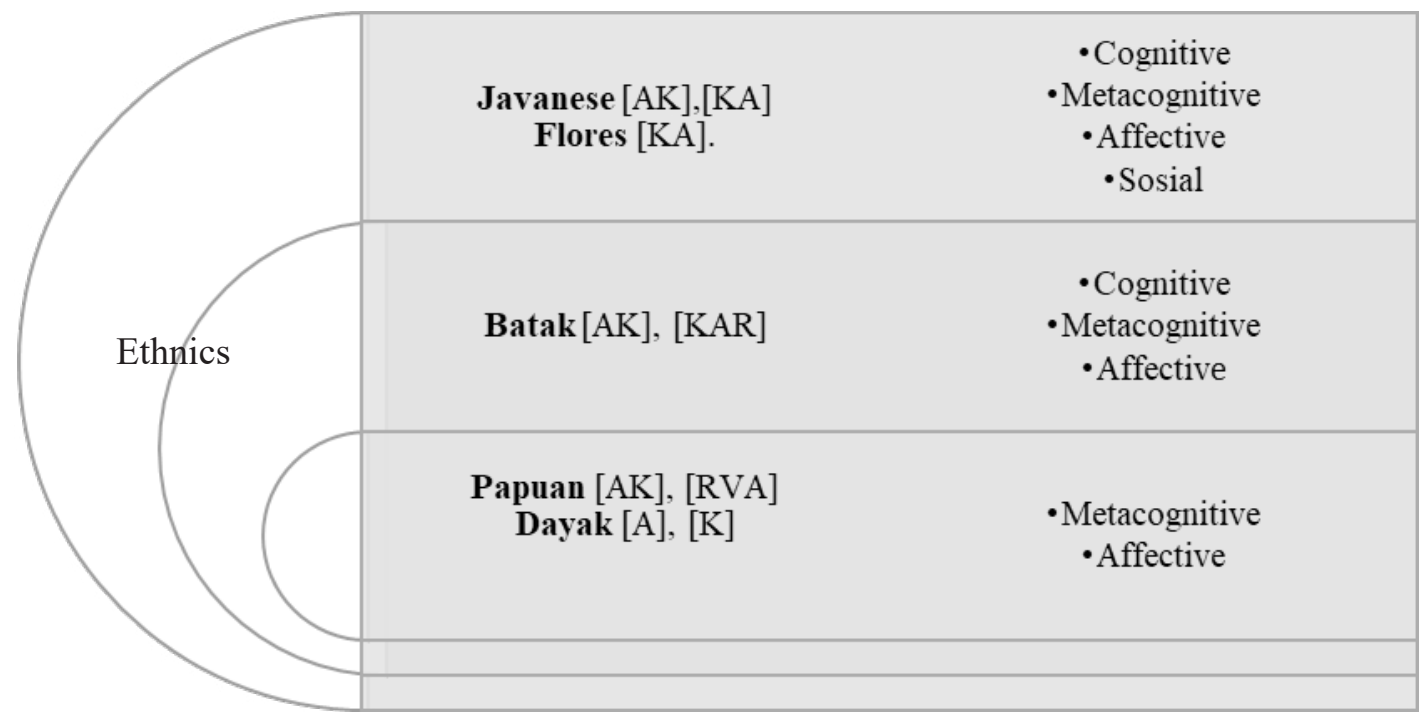

Figure 1. Language Learning Strategies of Students from Five Ethnic Group 
Further research in the learning style, language learning strategy, and ethnic identity in Indonesian learning need to be followed by linking effectiveness and efficiency of learning issues. This phenomenon is shown in Figure 1 that students from ethnic Javanese and Flores apply 4 language learning strategies namely Cognitive, Metacognitive, Affective and Social language learning strategies. The students from the Batak ethnic group using 3 language learning strategies such as Cognitive, Metacognitive, and Affective language learning strategies. Further, students from ethnic Papuans and Dayak only implement 2 language learning strategies namely Metacognitive and Affective language learning strategies. The hypothesis to be tested in the next research is the relationship or influence over the use of learning styles, language learning strategies, and the students' ethnic background in the effectiveness and efficiency of learning.

Jie \& Qin (2006) in his research on the Tertiary language learners in China, were able to demonstrate that the learning style had a significant influence on the way the learning strategy applied. Thus, in another words, learning style can give impact to the learning outcomes (Saadat \& Hosseini, 2015). Oxford shows that 'individual students' learning styles and strategies can work with-or conflicts with the instructional methodology given" (Oxford, 2001:45). In this connection, Ellis (2005) proposes an optimal type of instruction concept in accordance with the chosen individual learning approach, especially in this case is the learning style and language learning strategy.

The use of one method to teach is not beneficial to some students or even for most students. Especially if it is associated with the uniqueness of the style and learning strategy of the five ethnic students as presented in Figure 1. Lecturers' awareness of the various types of learning styles, language learning strategies, and the unique ethnic background of the students, as well as matching efforts with the teaching methods can help create an effective and efficient learning environment for all students. The more lecturers know about their students' style preferences, the more effectively they can direct their instruction. They also can use the teaching strategy that is interwoven into students' learning style preferences. Some learners may need instructions more visually, while some others may need more auditory, read/write, or kinesthetic. In addition, Reid (1995) has noted that the matching style of teaching with the learning style and language learning strategies will give all students the same opportunity in the classroom and build students' self-awareness.

\section{CONCLUSION}

The finding of the learning style shows in detail as follows. The Javanese has bimodal [Aural-Kinesthetic] and [Kinesthetic-Aural]. The Papuan has bimodal [Aural-Kinesthetic], and trimodal [Read/Write-Visual-Aural]. The Flores has bimodal [Kinesthetic-Aural]. The Dayak has unimodal [Aural] and [Kinesthetic]. The Batak has bimodal [Aural-Kinesthetic], and trimodal [Kinesthetic-Aural-Read/Write].

The findings of students' language learning strategies from the five ethnics indicate that metacognitive and affective strategies are "general" language learning strategies. Javanese and Flores use the same four language learning strategies: Cognitive, Metacognitive, Affective, and Social strategies. Papuan and Dayak use Metacognitive and Affective strategies. The Batak uses Cognitive, Metacognitive, and Affective. The Memory and Compensation are not applied by the Javanese, Papuan, Flores, Dayak, and Batak. The Social strategy is applied only by Javanese and Flores.

The findings of the similarities and differences in learning styles and language learning strategies of students from various ethnics show the facts as follows. Javanese and Flores have learning styles of bimodal [AuralKinesthetic] and language learning strategies of Cognitive, Metacognitive, Affective, and Social that tend to be identical. Papuan and Dayak do not share similarity in their learning styles but they have similar language learning strategies of Metacognitive and Affective. Metacognitive and Affective language learning strategies are applicable to Javanese, Flores, Batak, Papuan, and Dayak. Cognitive language learning strategy is applicable to Javanese, Flores and Batak. Social language learning strategies are only applicable to Javanese and Flores ethnic groups.

The results of this study are expected to be used to improve lecture planning and learning performance which is in line with Oxford's statement that learning styles and language learning strategies of the learners can be 
harmonized with the designed teaching methods (Oxford, 2001). Ellis (2005) also proposed the concept of matching instruction and learners.

\section{ACKNOWLEDGEMENT}

The authors would like to thank $\mathrm{P} 4$ or Pusat Penelitian dan Pelayanan Pendidikan (Center for Research and Educational Service) Sanata Dharma University, Yogyakarta.

\section{REFERENCES}

Ali, R., Indrawati, E. S., \& Masykur, A. M. (2010). Hubungan antara identitas etnik dengan prasangka terhadap etnik Taulaki pada mahasiswa Muna di Universitas Haluoleo Kendari Sulawesi Tenggara. [The relationship between ethnic identity and prejudice against ethnic Taulaki in Muna students at Haluoleo University, Kendari, Southeast Sulawesi]. Jurnal Psikologi UNDIP, 7(1), 18-26. doi:10.14710/jpu.7.1.18-26.

Bessai, N. A. (2018). Using Oxford's Strategy inventory of language learning. American Scientific Research Journal for Engineering Technology and Sciences (ASRJETS), 42(1), 166-187. https:// asrjetsjournal.org/index.php/American Scientific Journal/article/view/4019.

Demetriou, C., Ozer, B. U., \& Essau, C. A. (2015). Self-report questionnaires. In R. L. Cautin, \& S. O. Lilienfeld (Eds.). The encyclopedia of clinical psychology. New York, NY: John Wiley \& Sons Inc., pp. $1-5$.

Ellis, R. (2005). The study of second language acquisition. Shanghai: Shanghai Foreign Education Press.

Fitkov-Norris, E. D., \& Yeghiazarian, A. (2015). Validation of VARK learning modalities questionnaire using Rasch analysis. Journal of Physics: Conference Series, 588.012048, 1-6. doi:10.1088/1742$6596 / 588 / 1 / 012048$.

Fleming, N. D. (1995), I'm different; not dumb. Modes of presentation (VARK) in the tertiary classroom. In A. Zelmer (Ed.) Research and development in higher education, Proceedings of the 1995 Annual Conference of the Higher Education and Research Development Society of Australasia (HERDSA), pp. 308-313. https://vark-learn.com/introduction-tovark/bibliography/.

Fleming, N. D. (2012, January 15). Facts, fallacies, and myths: VARK and learning preferences. https://vark-learn.com/wpcontent/uploads/2014/08/Some-FactsAbout-VARK.pdf.

Fleming, N. D. (2014, October 1). The nature of preference. $\mathrm{https} / / / \mathrm{vark}$-learn.com/wpcontent/uploads/2014/08/THE-NATUREOF-PREFERENCE.pdf.

Fleming, N. D., \& Bonwell, C. (2019). How do I learn best? A learners' guide to improve learning. USA: Author.

Ghani, S. A., Khairisman, \& Samad, I. A. (2016). Investigating rural students' strategies in English Learning. International Journal of Education, 11(1), 68-77. doi:10.17509/ ije.v11i1.12836.

Gusnawati, G., \& Nurwati, A. (2018). Learning model of Bahasa Indonesia as a foreign language based on local intercultural politeness. Cakrawala Pendidikan, 38(1), 141-155. doi:10.21831/cp.v38i1.23164.

Hardan, A. A. (2013, 10 December). Language learning strategies: A general overview. Paper presented at The 4th International Conference on New Horizons in Education, Rome. doi:10.1016/j.sbspro.2013.12.194.

Jie, L. \& Qin, X. (2006). Language learning style and learning strategy of tertiary level English learner in China. RELC Journal, 37(1), 50-67. doi:10.1177/0033688206063475.

O’Malley, J. M., \& Chamot, A. U. (1990). Learning strategies in second language acquisition. Cambridge, UK: Cambridge University Press.

Oxford, R. (1990). Language learning strategies: What every teacher should know. Boston, MA: Heinle \& Heinle. 
Oxford, R. (2001). Language learning style and strategies: An overview. Birmingham: University of Alabama.

Oxford, R. (2003). Learning style \& strategies: An overview. GALA, 1-25.

Pashler, H., Mcdaniel, M.A., Rohrer, D., \& Bjork, R. A. (2009). Learning style concept and evidence. A Journal of the Assocation for Pshycological Sciene, 9(3), 105-119. doi:10.1111/j.1539-6053.2009.01038.x.

Rao, Z. (2016). Language learning strategies and English proficiency: Interpretations from information-processing theory. The Language Learning Journal, 44(1), 90106. doi:10.1080/09571736.2012.733886

Reid, J. M. (1995). Learning styles in the ESL/ EFL classroom. New York, NY: Heinle \& Heinle.

Robertson, L., Smellie, T., Wilson, P., \& Cox, L. (2011). Learning styles and fieldwork education students' perspectives. New Zealand Journal of Accupational Therapy, 58(1), 36-40. https://vark-learn.com/.
Saadat, M., \& Hosseini, S. A. (2015). The effect of ethnic identity and motivation on English language proficiency of Turk language learners. International Researchers, 4(3), 115-122. www.iresearcher.org.

Son, J. (2018). Back translation as documentation tool. The International Journal for Translation \& Interpreting Research, 10(2), 89-100. doi:10.12807/ ti.110202.2018.a07.

Trofimovich, P., \& Turuševa, L. (2015). Ethnic identity and second language learning. Annual Review of Applied Linguistic, 35(2015), 234-252. doi:10.1017/ S0267190514000166.

Wong, L. C., \& Nunan, D. (2011). The learning styles and strategies of effective language learners. System, 39(2), 144-163. doi:10.1016/j.system.2011.05.004.

$\mathrm{Xu}$, W. (2011). Learning style and their implication in learning and teaching. Theory and Practice in Language Studies, 1(4), 413-416. doi:10.4304/tpls.1.4.413416. 